\title{
Brucite-Aragonite Precipitates as Weathering Products of Historic Non-MgO-Based Geomaterials
}

\author{
Javier Martínez-Martínez ${ }^{1, * \mathbb{C}}$, David Benavente ${ }^{2} \mathbb{B}$, Nicoletta Fusi ${ }^{3}$ and Juan Carlos Cañaveras ${ }^{2}$ \\ 1 Spanish Geological Survey (IGME), Calle Ríos Rosas, 23, 28003 Madrid, Spain \\ 2 Department of Earth Sciences and the Environment, University of Alicante, Apdo. Correos 99, \\ San Vicente del Raspeig, 03080 Alicante, Spain; david.benavente@ua.es (D.B.); jc.canaveras@ua.es (J.C.C.) \\ 3 Department of Environmental and Land Sciences and Earth Sciences. Univeristy of Milano-Bicocca, \\ 20126 Milan, Italy; nicoletta.fusi@unimib.it \\ * Correspondence: javier.martinez@igme.es
}

Received: 10 June 2020; Accepted: 25 June 2020; Published: 30 June 2020

\begin{abstract}
This paper analyses the mineralogical composition, texture, and structure of a stalactite sampled from the city-wall storerooms of the Nueva Tabarca fortress (southeast Spain). This speleothem presents an uncommon mineral assemblage: aragonite, brucite, gypsum, silica, and halite. Internally, it shows complex structure: (1) a central soda-straw composed by aragonite; (2) an external puff-pastry cone-crust formed preferentially by aragonite and brucite; and (3) an internal branching of coralloids, showing a subtle layering between brucite and aragonite. Gypsum, halite, and silica locate in the outer coating of the cone-crust. The sequent mineral precipitation sequence has been established: aragonite $>$ brucite $>$ gypsum/silica $>$ halite. Speleothem formation is directly related to the chemical weathering of the rocks and mortars used as building materials of the city-wall. Brucite precipitates has been always linked to the presence of $\mathrm{MgO}$-based geomaterials. However, the lack of these compounds as building materials in Nueva Tabarca fortress makes this investigation a unique example of brucite precipitation. PHREEQC calculations showed that interaction between pore waters and the minerals of mortar aggregates (dolomite, pyroxene, and amphibole) leads to rich-magnesium solutions. Evaporation modelling of lixiviated waters describes the precipitation of the mineral assemblage of the brucite-aragonite speleothems.
\end{abstract}

Keywords: brucite; X-ray computed tomography; speleothem; stalactite; geochemistry

\section{Introduction}

The presence of brucite $\left(\mathrm{Mg}(\mathrm{OH})_{2}\right)$ as constitutive of building materials in cultural heritage is very scarce and it is almost exclusively limited to dolomitic limes [1,2]. The main mineral phases in dolomitic limes are portlandite $\left(\mathrm{Ca}(\mathrm{OH})_{2}\right)$ and brucite that react during the carbonation process, out of which comes out calcite $\left(\mathrm{CaCO}_{3}\right)$, hydromagnesite $\left(\mathrm{Mg}_{5}\left(\mathrm{CO}_{3}\right)_{4}(\mathrm{OH})_{2} \cdot 4 \mathrm{H}_{2} \mathrm{O}\right)$, and a variety of hydroxycarbonates whose formation depends on the water content of the mortar as well as the carbon dioxide and moisture content of the air [3]. In the past, the choice of using dolomitic or calcitic limes in constructions depended mostly on the availability of the geological source (namely the proximity to stone quarries to be exploited for obtaining the raw materials) [1].

Brucite is also found as weathering product of cement-based materials, resulting from the dissolution and reprecipitation of ions from the cement past and pore waters, especially in marine exposure [4-6]. Brucite, in these cases, use to form layered precipitates, frequently intermixed with other mineral phases (i.e., calcite, aragonite, and ettringite) filling cracks in the concrete mass. These fillings can close totally or partially the initial fracture, making difficult the ingress of aggressive substances and improving the durability of the structure. Self-healing mechanisms in cementitious materials can 
be promoted using suitable healing agents [7]; however, sometimes it occurs spontaneously without previous design in an autogenetic self-healing $[6,7]$.

Further constructive contexts where $\mathrm{Mg}(\mathrm{OH})_{2}$ can be presented in geomaterials are related to special binders. On the one hand, $\mathrm{MgO}$ can be added in repair mortars as alkali-activated slag in order to enhance their mechanical properties, bonding performance and workability $[8,9]$. In this case, brucite can be found as hydrated product results from the reaction of magnesium oxide with water [10]. On the other hand, $\mathrm{MgO}$-based cements, where $\mathrm{MgO}$ is used as the main binder, have been used in industrial practices, for more than 150 years, as an alternative paste to ordinary Portland cement [11]. The major benefits of $\mathrm{MgO}$ cement are the relatively lower calcination temperatures used during its production and its ability to gain strength by carbonation curing. The hydration of $\mathrm{MgO}$ during the first stages of the process results in the formation of brucite, which gives rise to the formation of a variety of hydroxycarbonates during $\mathrm{CO}_{2}$ curing.

All these materials and additives (dolomitic limes, $\mathrm{MgO}$-based cements, $\mathrm{MgO}$ slags, and even Portland cement) have been previously identified as Mg-sources in all the bibliographic cases where brucite appears in constructional contexts. However, to the best of the authors' knowledge, the current study case constitutes the unique published example where brucite is the main weathering product of historic building materials where none of them are present. The weathering products studied in this paper constitute chemical precipitates developed over the both the ceiling and the walls of two vaulted rooms located in the lower internal level of the city-wall of Nueva Tabarca (southeast Spain). Therefore, this case constitutes a particular case study due to the fact that an alternative Mg-source for the brucite precipitates must be found.

This paper aims therefore, to characterize both the mineralogy and texture/structure of the weathering products sampled from the city-wall of Nueva Tabarca village, paying special attention to $\mathrm{Mg}$ provenance as well as to the analysis of the geochemical conditions in which its dissolution and reprecipitation takes place. The unusual mineral assemblage of these precipitates and their complex both textures and structures highlight the interest of this study. Moreover, findings obtained from this work contribute to the knowledge of the brucite stability under real conditions, contributing new examples of the brucite precipitation contexts as well as to the background studies about autogenic shelf-healing processes.

\section{Case Study, Local Geology, and Raw Materials Characterization}

Nueva Tabarca is a small island (1800 $\mathrm{m}$ in length and $450 \mathrm{~m}$ in width) located at $22 \mathrm{~km}$ from Alicante city (southeast Spain, Figure 1). In the western part of the island, a fortified settlement was built in the 18th century. Nowadays, the Nueva Tabarca fortified village constitutes an exceptional example of homogeneous baroque architectural heritage protected under several local and national figures [12]. One of the most distinctive elements of the architectural complex is the defensive structure. The city-wall is a robust construction adapted to the irregular coastline that reaches up to $10 \mathrm{~m}$ width in its widest segments. At these points, several storerooms were built in the inner lower level of the construction (Figure 2). Currently, the ceiling and walls of these storerooms are covered by chemical precipitates forming crusts and stalactites (Figure 2), which are the study object of this work.

The city-wall was built with regular stone ashlars in its external surfaces whereas the inner volume was filled by masonry (Figure 2). Due to the insularity conditions, the building materials supply was restricted to the local resources. In this sense, the architectural ensemble can be considered as a self-supplied system in which local geological resources are optimized and exploited.

From a geological point of view, the island can be divided in two sectors according to the spatial distribution of rocks (Figure 1). The eastern sector of the island consists of a basement of fine-grained metagabbros, grey limestones, and orange dolosilts, all of them Triassic in age [13]. The Triassic basement is overlaid by a thin layer of Quaternary red silts and marine conglomerates. The western sector is dominated by a thick calcarenite deposit that overlies an erosive unconformity with the lower 
Triassic materials [14]. These calcarenites, Late Miocene in age [15,16], were called "Tabarca Unit" by [16] and they are interpreted as an open marine platform grading upwards to more distal deposits.

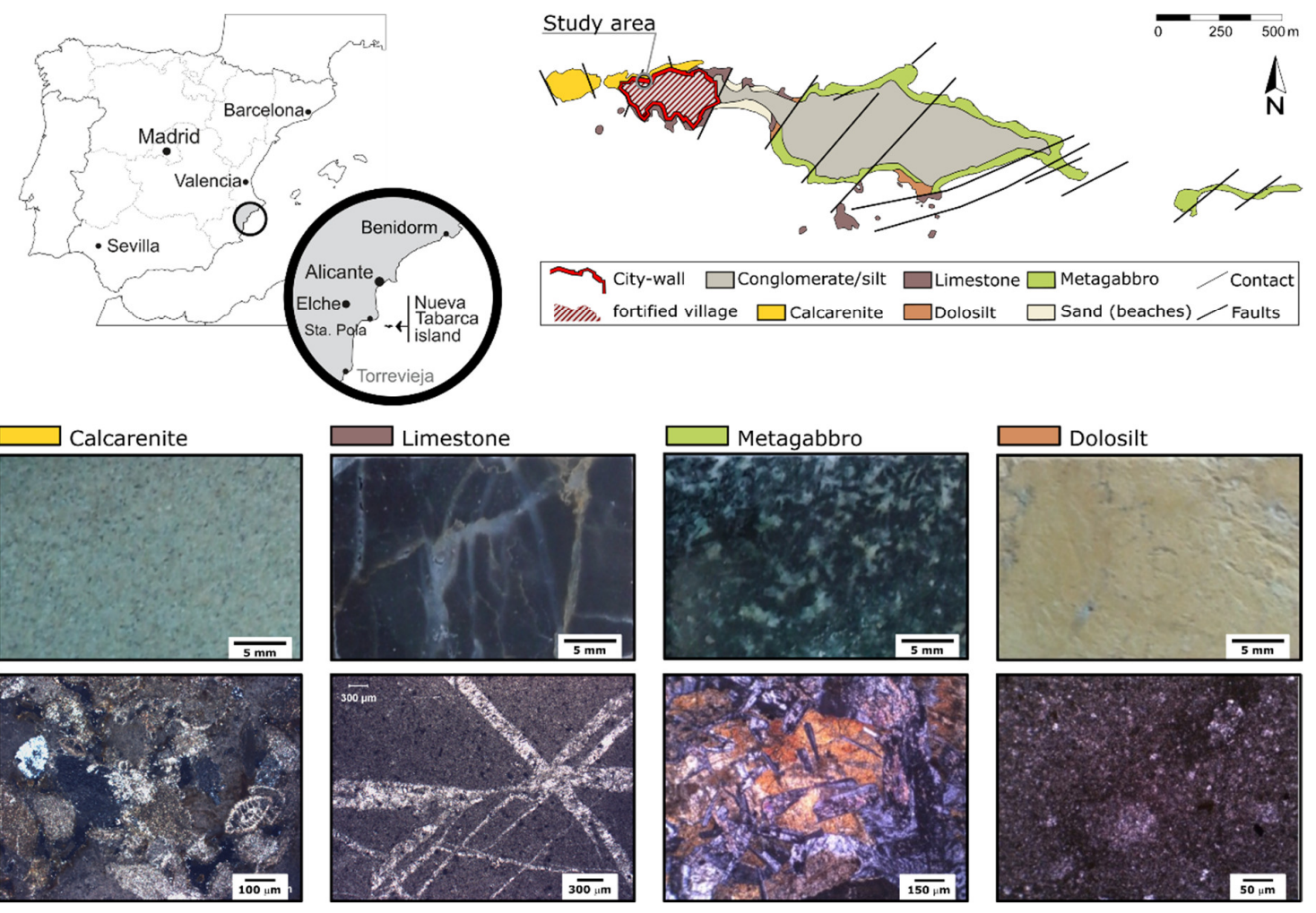

Figure 1. Location (top left) and geological map (top right) of Nueva Tabarca island. Photographs (first raw) and photomicrographs (second raw) of the main lithologies used as building rocks in the architectural heritage of the island.

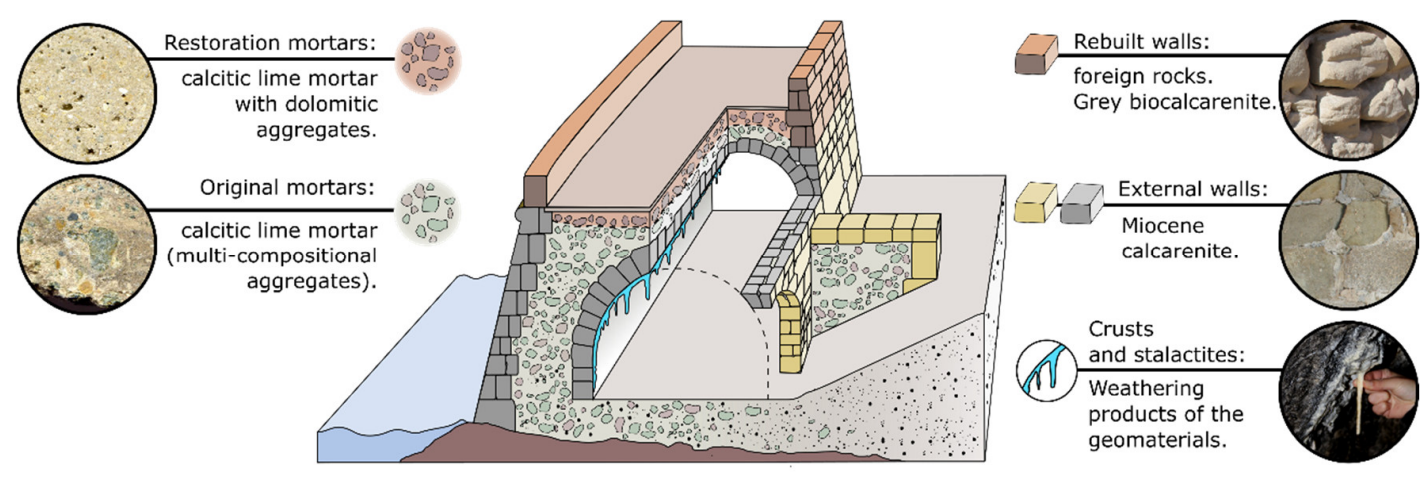

Figure 2. Constructive sketch of the city-wall of Nueva Tabarca showing the location of the studied vaulted storerooms and the used geomaterials of the building.

Most of these rocks were used as raw materials for the construction of the Nueva Tabarca fortification. Firstly, the rock with the best characteristics for ashlars carving and sculptural elements was the Miocene calcarenite (Figure 1). Consequently, it was the main building material used in the outer parts of the city wall (Figure 2). Secondly, both grey limestones and metagabbro blocks were used as rubble stones included in the masonry filling of the construction. Finally, both metagabbro and dolosilt gravel (mainly collected from beach deposits) were incorporated to lime mortars as aggregates.

Petrographically, calcarenites are characterized by a variable content of both bioclasts (mainly algal rhodolith and briozoa fragments) and lithoclasts (rock fragments of both volcanic rocks and limestones), as well as by a variable average grain size, defining both calcarenite (average grain size 
lower than $2 \mathrm{~cm}$ ) and calcirudite levels $(>2 \mathrm{~cm})$ throughout the stratigraphic deposit. A complete description of these rocks (and the different lithostratigraphic levels) can be found in [17]. Grey limestones correspond to a homogeneous equigranular cryptocrystalline rock with frequent veins filled with white calcite cement (Figure 1). Metagabbro is a dark-green medium to coarse-grained rock. Crystals of augite and hornblende enclose tabular crystals of plagioclase in ophitic textures (Figure 1). These crystals show slightly to moderate alteration degree. Finally, dolosilt is a yellowish-orange deposit composed of low-consolidated (or even unconsolidated) silt-sized dolomite grains.

Table 1 shows the mineralogical composition of all the rock types used as raw materials in the construction of the Nueva Tabarca fortified village.

Table 1. Average values of mineral content (\%) of the Nueva Tabarca geomaterials analyzed using X-ray diffraction. Px: pyroxene; Plg: plagioclase; Ep: epidote; $\mathrm{Cl}$ : chlorite; Anf: amphibole; Btt: biotite; Qtz: quartz; Cc: calcite; Dol: dolomite; Ill: illite; and * trace content. Values in brackets refer to mineral composition of mortar aggregates.

\begin{tabular}{ccccccccccc}
\hline \multicolumn{10}{c}{ Original Building Materials } \\
\hline Building Material & Px & Plg & Ep & Cl & Amph & Btt & Qtz & Cc & Dol & Ill \\
\hline Metagabbro & 9.8 & 25.6 & 5.5 & 13.7 & 25.0 & 8.4 & 12.0 & - & - & - \\
Grey Limestone & - & - & - & - & - & - & $*$ & 99.9 & $*$ & - \\
Calcarenite & - & - & - & - & - & - & 5.7 & 77.8 & 11.1 & $*$ \\
Dolosilt & - & - & - & - & - & - & 4.5 & 30.3 & 55.1 & 10.1 \\
Lime mortar & - & $(18.8)$ & - & - & $(20.7)$ & - & $(4.9)$ & 39.9 & $(14.4)$ & - \\
\hline & & & Restoration materials & & & & & \\
\hline Building Material & Px & Plg & Ep & Cl & Amph & Btt & Qtz & Cc & Dol & Ill \\
\hline Lime mortar & - & - & - & - & - & - & $(4.2)$ & 45.2 & $(50.4)$ & - \\
Biocalcarenite & - & - & - & - & - & - & 20.2 & 68.4 & $*$ & 11.4 \\
Biocalcirudite & - & - & - & - & - & - & 2.5 & 97.5 & - & $*$ \\
\hline
\end{tabular}

Historic lime mortar was also made from local resources (grey limestones) in the ancient limekiln built expressly in the island. Their composition corresponds to calcite in all cases (Table 1).

The aggressiveness of the local environment causes the fast deterioration of the city-wall [18] and it was restored during the decade of 1970, incorporating local and foreign building stones as reintegration materials. A grey biocalcarenite from inland quarries (Novelda Stone, [19]) and a detrital limestone (biocalcirudite) were used as new building stones. The mortar used in the modern reconstructions was calcitic lime mortars (with dolomitic aggregates) in all cases (Table 1).

\section{Methodology}

Two speleothem samples were collected from the ceiling of the room; most of the analysis being focused on the stalactite due to its higher textural complexity (Figure 3). Firstly, the stalactite structure and its inner textures were studied in a non-destructive way using a high-resolution X-ray computed microtomography ( $\mu \mathrm{CT}-\mathrm{RX}$ ) (Figure 3E). After that, stalactite was cut in three fragments (Figure 3F), using both the first and the last one (s1 and s3 in Figure 3F) for the mineralogical determination and the central one (s2) for textural observations.

The $\mu C T-R X$ system used in this study is a BIR Actis 130/150 with a polychromatic $X$ rays generator (Bio-Imaging Research Inc., Lincolnshire, IL, USA). Energy of $100 \mathrm{keV} / 80 \mathrm{~mA}$ was used to scan the sample. 3D images were reconstructed both with Actis and Avizo-Fire software (v.n. 2019.2, Thermo Fisher Scientific, Waltham, MA, USA). The dimensions of the voxel, corresponding to the resolution of the images, were $10 \times 10 \times 10 \mu \mathrm{m}$.

Samples for mineralogical analysis were powdered using an agate mortar and they were analyzed by means of X-ray diffractometry using a Bruker D8-Advance diffractometer (Bruker, Karlsruhe, Germany). Diffractometer is equipped with a generator of X-ray Kristalloflex K 760-80F (3000 W, 
voltage: $20-60 \mathrm{KV}, 4-70^{\circ} 2 \theta$ explored area and current 5-80 mA, Bruker, Karlsruhe, Germany) with a tube of RX with copper anode.
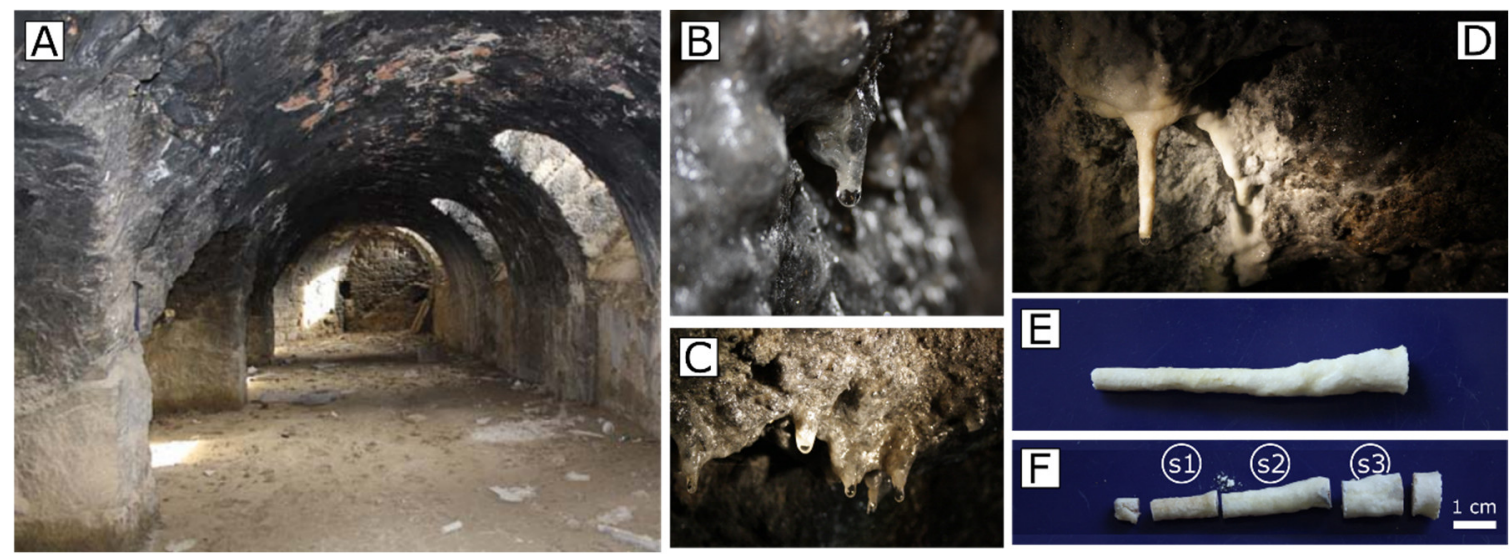

Figure 3. (A): general view of the studied storeroom. (B) and (C): details of different dripping points and initial stages of stalactites. (D) and (E): Studied stalactite. (F): samples obtained for mineralogical analysis (s1 and s3) and textural observations (s2).

Inner textures and structures were observed under scanning electron microscope in backscattering electron mode (BSE-SEM). To do so, the central fragment of the stalactite was cut along its both cross and longitudinal sections. Uncovered surfaces were studied in a HITACHI S-3000 N (Oxford Instruments plc, Abingdon, UK) variable pressure SEM working at low vacuum. An energy dispersion spectrometer (Bruker-XFlash 3001 EDS, Oxford Instruments plc, Abingdon, UK) was attached for chemical microanalysis and compositional mappings.

The geochemical reaction of dissolution-precipitation was modelled with PHREEQC code using 3.4.0 version (USGS, Reston, VA, USA) [20]. PHREEQC calculated the saturation index, SI, as SI = log (IAP/K). IAP is the ion activity product and $\mathrm{K}$ is the equilibrium constant. The saturation index determined, from thermodynamically point of view, whether the water was saturated (equilibrium, $\mathrm{SI}=0$ ), undersaturated (mineral dissolution, $\mathrm{SI}<0$ ), or supersaturated (mineral precipitation, $\mathrm{SI}>0$ ), with respect to the given mineral or phase.

The geochemical reaction simulations involved two steps: (1) the estimation of the composition of lixiviated waters. We considered that these reactions were produced in contact with deionized water in order to simulate the interaction with meteoric water, in isothermal conditions (temperature $=15^{\circ} \mathrm{C}$ ). According to the microstructure properties of mortars, we established that the residence time of the meteoric waters inside of the mortar was sufficient to dissolve calcite until reaching the saturation $(\mathrm{SI}=0)$, whereas the less reactive Mg-bearing minerals remained unsaturated. According to their reactivity $[21,22]$, we computed that the $\mathrm{SI}=-0.5$ for dolomite and $\mathrm{SI}=-2.0$ for diopside and tremolite. (2) Evaporation was accomplished by removing water an irreversible reactant with a negative reaction coefficient through REACTION keyword. We used the Minteq thermodynamic database for the equilibrium constants.

\section{Results}

Mineralogical determination of speleothems using X-ray diffraction showed that they are mainly composed of brucite $(49 \%)$, aragonite $(24 \%)$, gypsum $(19 \%)$, halite $(8 \%)$, and amorphous silica (identified by the broad peak at low diffraction angles). This mineralogical composition remained quasi-constant along the whole stalactite, registering a slight increase in the salt content in the lower sample (the closest one to the tip).

Stalactites presented a complex structure with three differentiated parts (Figure 4): (a) central soda straw, (b) external puff-pastry cone-crust, and (c) branching of coralloids. Similar structures have 
been reported by [23] developed in artificial environments such as tunnels, bridges, and cellars. In all these cases, speleothems present a tufaceous mineral texture that is associated to their formation from crack-fed solutions suffering sudden pressure, temperature, or moisture changes.
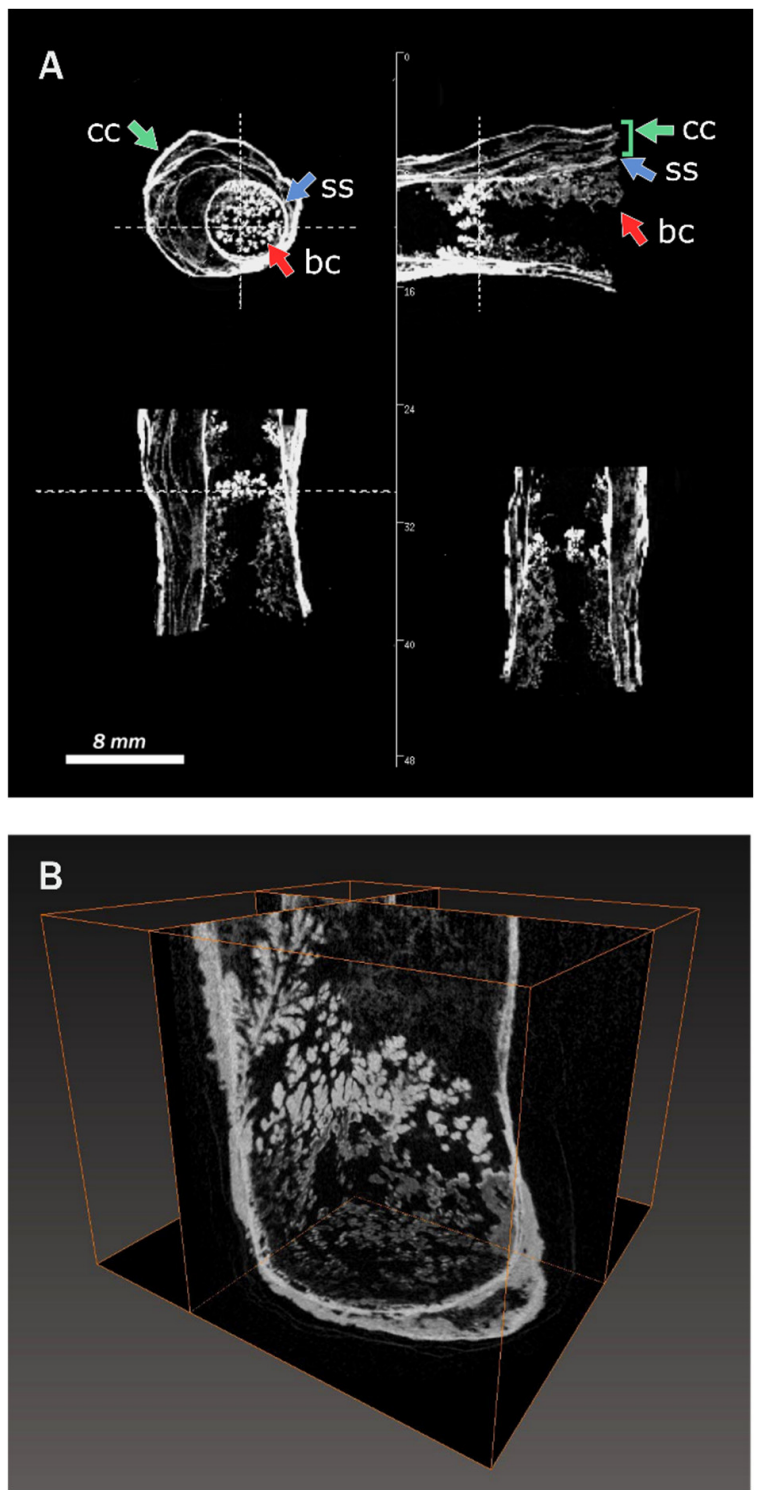

Figure 4. Inner structure of the studied stalactite studied by means of microCT-RX. (A) Orthogonal sections showing the main structural elements (cc: cone-crust; ss: soda-straw; and bc: branching of coralloids). (B) 3D reconstruction of the stalactite.

Observations under BSE-SEM and EDS mapping show a spatial segregation of the different mineral phases (Figure 5). The soda-straw are preferentially composed by aragonite, while the external crust structure includes brucite, aragonite, gypsum, silica, and halite.

The quasi-layered arrangement of brucite and aragonite in the cone-crust, instead formed a homogeneous mixed mass with both minerals, indicating that there exists a mineral precipitation sequence. The complex relationship between both phases makes it difficult to stablish the order in which they precipitate. However, the free-growing botryoidal structures developed by aragonite, covered at some points by dense brucite masses (Figure 5A), suggests that aragonite precipitated first. Moreover, the cone-crust presents a primary structure composed of thick asymmetrical concentric rings of aragonite. Hollows between them were mostly filled by brucite (Figure 5C), reinforcing the idea of an aragonite $>$ brucite sequence. Similar mineral sequences were found in [24]. 
Cone-crust
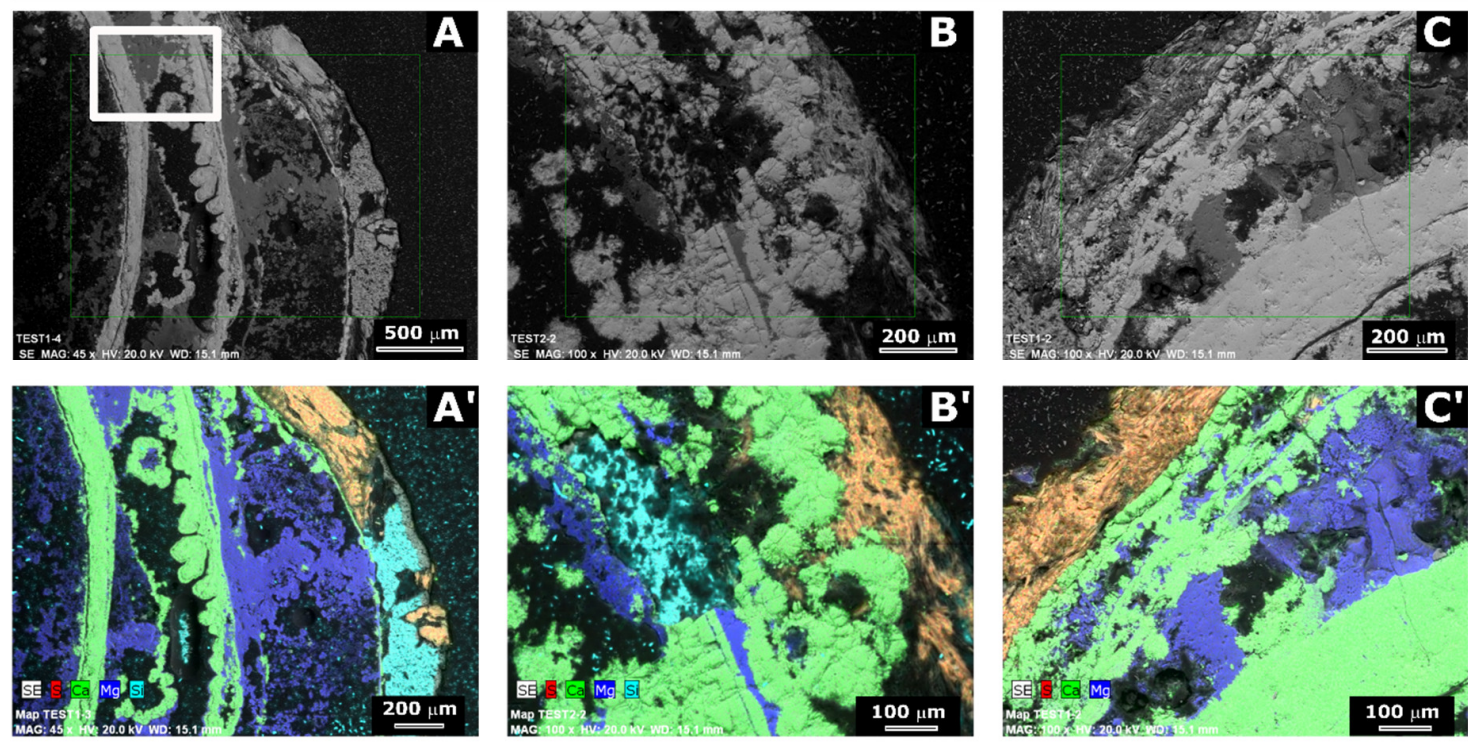

Branching of coralloids
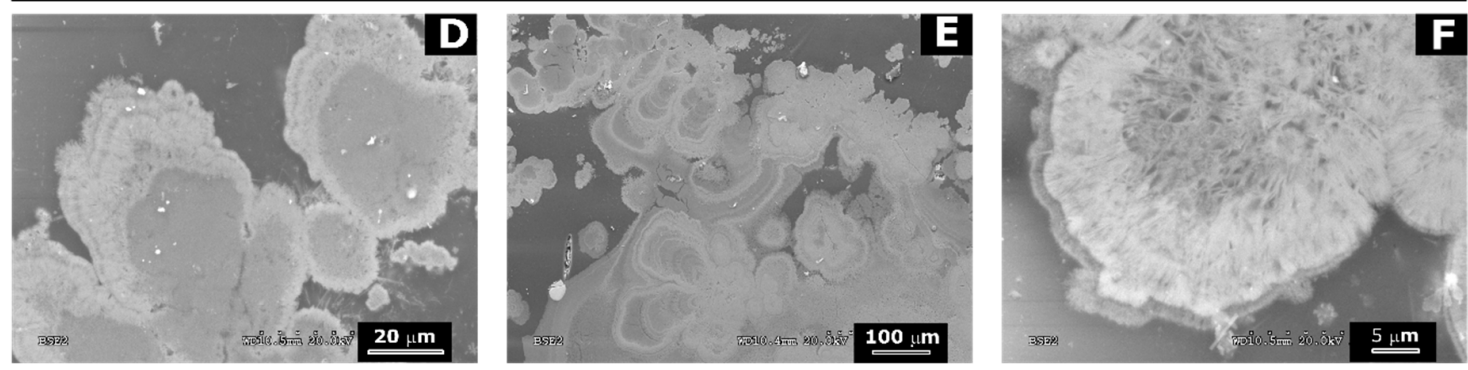

Aragonite and brucite textures
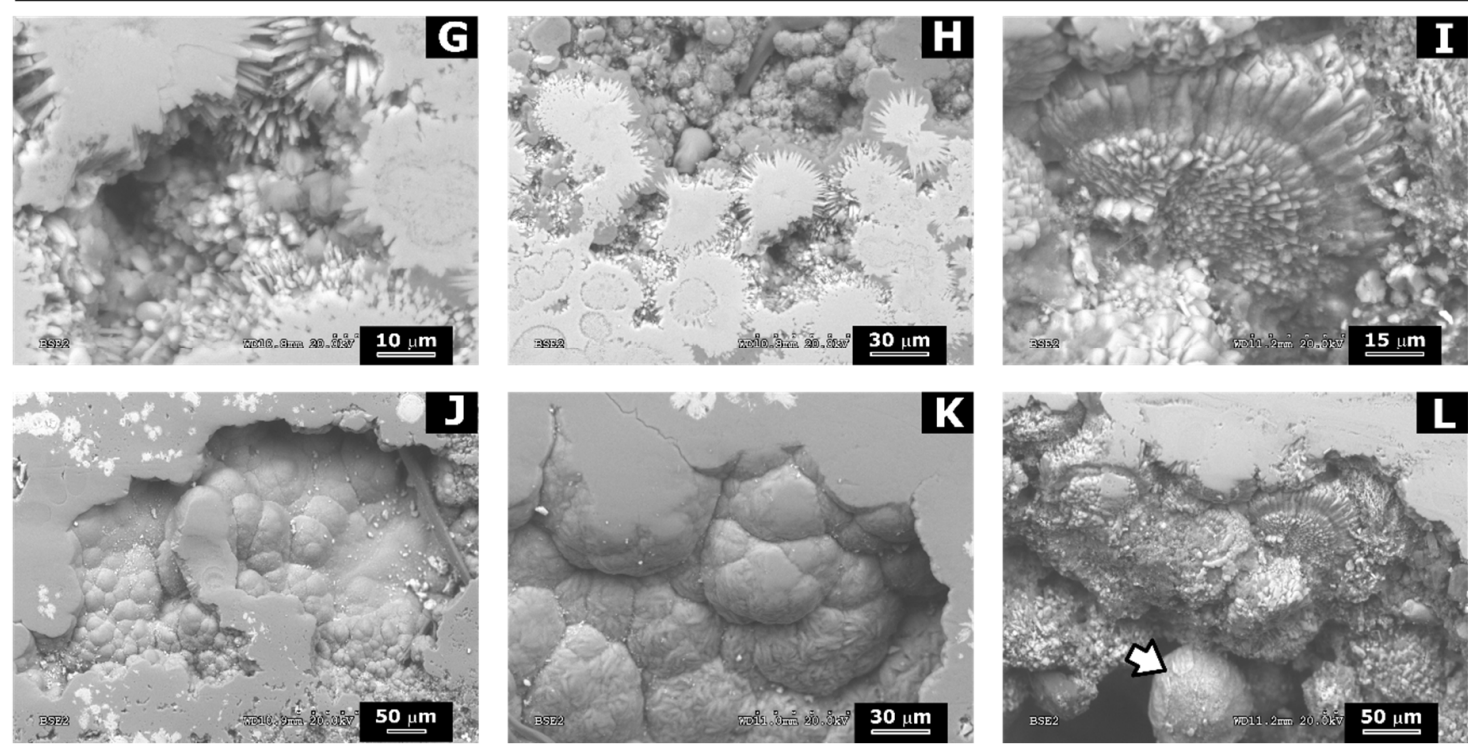

Figure 5. Scanning electron microscope in backscattering electron mode (BSE-SEM) images (A-L) and geochemical mappings $\mathbf{A}^{\prime}, \mathbf{B}^{\prime}$, and $\mathbf{C}^{\prime}$ ) of different parts of the stalactite. Colour code of the geochemical maps: green $>\mathrm{Ca}$; blue $>\mathrm{Mg}$; orange $>\mathrm{S}$; and turquoise $>\mathrm{Si}$. Grey level code of BSE-SEM images: dark grey $>$ brucite; light grey $>$ aragonite. Images $(\mathbf{G}-\mathbf{H})$ correspond to aragonite textures in the branching of coralloids. Images $(\mathbf{J}, \mathbf{K})$ correspond to brucite botryoidal textures in the branching of coralloids. Image (L) shows aragonite radial textures of the cone-crust (image (I) shows a detail of a fibrous aragonite crystals fan). The arrow in image (L) indicates a sphere of brucite on the surface of the aragonite precipitate. 
Figure 5A shows the outer position of irregular silica-gypsum layers in the cone-crust. At some points, silica filled corrosive gaps developed in the aragonite-brucite structures (turquoise masses in Figure 5B), as well as gypsum precipitates accommodated on the irregular shape of botryoidal aragonite masses (orange phases in Figure 5B). Consequently, the sequent mineral precipitation sequence is proposed: aragonite $>$ brucite $>$ gypsum/silica $>$ halite.

Branching of coralloids were formed exclusively by aragonite and brucite, showing a subtle layering between both minerals (Figure 5).

Aragonite exhibited high diversity of crystalline textures, from massif cementation texture in the soda-straw to striking acicular, to needle-like morphologies forming spheroidal aragonite clusters in the inner coralloids (Figure 5G,H). Aragonite layers in the outer cone-crust alternated from massif to blocky textures that became needle-like in the internal part (facing the center of the stalactite). The most frequent aspect of the brucite masses was the compact texture, varying at some points to brucite cluster of interlocking flakes with narrow spaces between crystals. In the surrounding of the soda-straw, brucite also occurred as botryoidal masses with amorphous forms (Figure 5J,K). Finally, gypsum and silica precipitates appeared as amorphous and massive fillings of the space between the brucite-aragonite layers of the external levels of the cone-crust (Figure $5 \mathrm{~A}^{\prime}$ ).

\section{Discussion}

\subsection{Magnesium Provenance}

Previous published papers linked the presence of brucite in constructive contexts to the use of specific building materials such as MgO-based binders (dolomitic limes or MgO-based cement) [1,11], Portland cement [5], or mortars with $\mathrm{MgO}$ additives [8]. However, Table 1 shows that none of them are present in the city-wall of Nueva Tabarca fortress. In this case, other Mg-rich minerals are present in the rocks used as aggregates in both original and restoration calcitic mortars. Dolomite (from dolostones and dolosilt) and pyroxene and amphiboles (from metagabbro) act as $\mathrm{Mg}$-sources, providing $\mathrm{Mg}$-ions to the pore water. Nevertheless, these Mg-bearing minerals are more stable, and their dissolution will occur, but in lower proportion compare to calcite. Thus, dolomite is chemically very stable and its dissolution rate is estimated to be lower by a factor of 3 to 60 than these of limestones [25]. Similarly, pyroxenes and amphiboles also present even a lower chemical reactivity [22]. Consequently, $\mathrm{Mg}$ enrichment of the pore water only occurs when the water flux is low enough for allowing the effective interaction between water and minerals.

Accordingly, two situations are contemplated depending on the residence time of the meteoric water flowing through the built structure:

1. Long residence times associated with meteoric water flowing slowly through the calcitic mortars. Flux is low through these geomaterials due to their complex porous systems, which are characterized by open porosity values ranging between $15.26 \%$ and $23.33 \%$ and average porous radius of $1.4 \mu \mathrm{m}$. According to this pore structure properties, the mortar permeability can be classified as very-low permeability material (under $1 \mathrm{mD} \sim 10-15 \mathrm{~m}^{2} \sim 10-8 \mathrm{~m} / \mathrm{s}$ [26]). In this case, meteoric water dissolves the calcite of the calcitic lime due to its higher solubility, increasing the relative proportion of $\mathrm{Ca}^{2+}$ and $\mathrm{CO}_{3}{ }^{2-}$ into the solution. Nevertheless, the long residence time also allows the effective dissolution of the less soluble minerals, transferring $\mathrm{Mg}^{2+}$ to the pore water from dolomite, pyroxene, and amphibole. The magnesium present in the lixiviate water is significant due to the high-volume fraction of the Mg-bearing minerals in both original and restoration mortars (Table 1).

2. Short residence times associated with meteoric water flowing rapidly through fractures and ashlar joins. High water flow occurs during heavy rains and causes a low interaction water-minerals. The associated lixiviate water is low chemically modified.

In both cases, the proximity of the sea constitutes a secondary source of magnesium. Pore system of building materials is partially saturated with meteoric water influenced by wave-splash and sea 
spray due to its location in the supralittoral zone. $\mathrm{Mg}$ in marine and coastal rain is $6 \times 10^{-6} \mathrm{~mol} / \mathrm{L}$ [21] In spite of the fact that these quantities are much lower than those transferred from mineral dissolution, a small magnesium contribution to the water system can be attributed to the sea spray.

Rainfall regime in the Nueva Tabarca island is characterized by long periods of drought, with sporadic torrential rainfalls, especially during autumn and winter [18]. Therefore, the predominant situation in the water system of the city-wall is the low flows throughout the mortars (situation 1), with occasional fast water circulation through fractures and/or ashlar joins during rainfalls (situation 2).

To estimate the geochemistry evolution of the pore water, we calculated with PHREEQC the interaction between water and mineral assemblage in the mortar. We considered that calcite dissolution is produced until reaching the saturation $(\mathrm{SI}=0.0)$ whereas the less reactive $\mathrm{Mg}$-bearing minerals remain unsaturated ( $\mathrm{SI}=-0.5$ for dolomite and $\mathrm{SI}=-2.0$ for diopside and tremolite) at $15^{\circ} \mathrm{C}$. Under these conditions, concentrations of calcium, magnesium, total carbon, and silica in the lixiviated waters were, respectively, $1.23 \times 10^{-4}, 4.49 \times 10^{-5}, 6.53 \times 10^{-5}$, and $6.95 \times 10^{-8} \mathrm{~mol} / \mathrm{kg} \mathrm{H}_{2} \mathrm{O}$, and an alkaline $\mathrm{pH}$ value of 10.67 .

\subsection{Textural/Structural Analysis and Precipitation Sequence}

Soda straw is formed in association with water drops that come off from the roof (Figure 3B,C) and it is considered as the first and basic structure from which the stalactite growths and develops. The formation of the subsequent conical envelope is due to the crystallization from lixiviated water flowing on the external walls of the speleothem. At the beginning, the crust formation follows the soda straw creation, but after this first stage, both structures form together and simultaneously [23]. The composition, thickness, and morphology of the asymmetrical concentric rings and hollows of the cone-crust around the central soda straw suggests environmental changes (even hiatuses) in the development of the speleothem.

Branching of coralloids covers the inner surfaces of the central channel of the stalactite. It is globular in shape and its well-developed and complex structure indicates quiet and steady precipitation conditions [27].

Therefore, the central soda straw constitutes a division structure that defines two differentiated microenvironments (Figure 6): the outer surface where the cone-crust develops strongly influenced by the room conditions, and the inner volume where branching of coralloids grows partially isolated from external variations.

\subsubsection{Cone-Crust Formation}

The development of the cone-crust is strongly discontinuous, controlled by the regular succession of growth events (dominated by mineral precipitation), and both corrosive (dissolution) and non-corrosive (lack of precipitation) hiatuses [23].

\section{Growth Events}

Constructive events are associated with precipitation from Mg-enriched lixiviate waters (described in the situation 1 of the Section 5.1). Figure 6A shows the proposed hypothetical constructive sequence for a single envelop of the cone-crust. Particularly, Figure 6A could represent the formation of the area market in Figure 4A (white square). Proposed sequence starts when a stable water film covers the outer perimeter of the soda-straw and a rapid evaporation of the lixiviated water takes place (Figure 6: A-1). Under these conditions, a thin aragonite layer appear in the water-air interface (Figure 6: A-2), creating an asymmetrical concentric ring in the cone-crust deposit corresponding to the perimeter of the covering water film (see stalactite cross section in Figure 4A). Aragonite layers show the sequent textural evolution (Figure 5A-C): thin massive (or fine-grained blocky texture) crust (Figure 6: A-2); irregular (botryoidal) massive layer (Figure 6: A-3) and; finally, a thin fibrous aragonite layer that covers completely the residual cavity (Figure 6: A-4). This set becomes the substrate for later growth of brucite, massive in texture (sometimes in spherical aggregates) at the first stages and crystalline 
(with narrow spaces between the flaky crystals) later on (Figure 6: A-5). Similar mineral and textural sequences were observed in the crystalline crusts precipitated at the air-water interface of the alkaline spring systems of Oman [24]. In fact, similar aragonite-brucite sequences are very common in the crack pieces of self-healed Portland cement concrete exposed to seawater $[5,6,28]$.

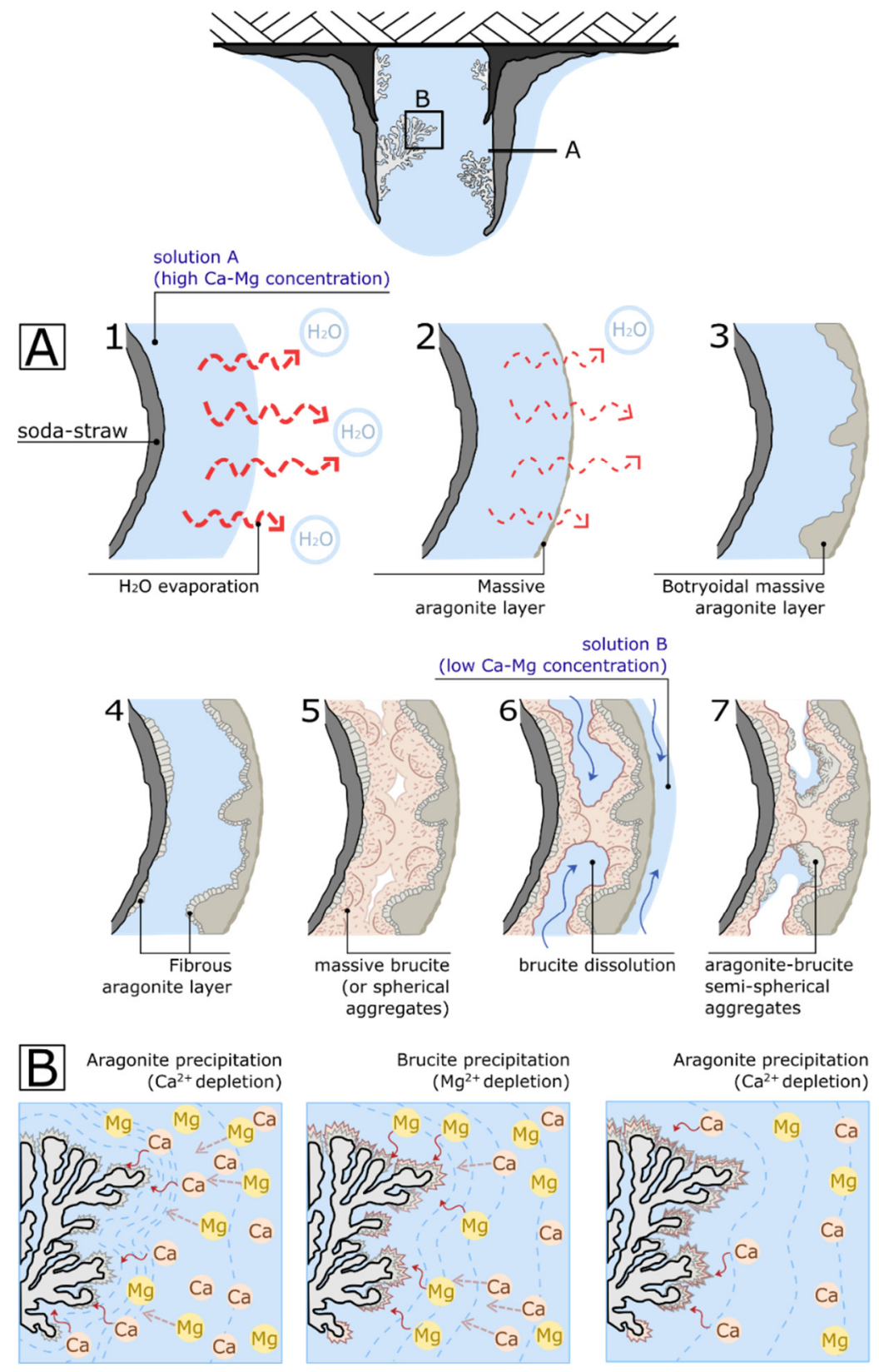

Figure 6. Sketch of the suggested genesis of the studied stalactite. The final obtained structure corresponds with that market in Figure 4a (white square). (A) sequence of the formation of the cone-crust. (B) Formation of the branching of coralloids (blue dished lines represent solute concentration isopleths).

The evolution from massive to fibrous aragonite firstly and from massive to flaky brucite secondly indicate an initial increase of the $\mathrm{Mg} / \mathrm{Ca}$ ratio in the solution (associated to the aragonite precipitation) followed by a $\mathrm{pH}$ decrease as the brucite formation implies a consumption of hydroxyl ions $\left(\mathrm{OH}^{-}\right)$. On the one hand, the presence of $\mathrm{Mg}^{2+}$ ions favors the development of fibrous aragonite crystals $[24,29,30]$. On the other hand, the size and morphology of brucite crystals depends strongly 
on $\mathrm{pH}$ [31]. High $\mathrm{pH}$ values $(\mathrm{pH}>11.5)$ favor the crystal nucleation against the crystal growth and consequently brucite appears as micro-crypto crystalline masses. When $\mathrm{pH}$ is lower than 11.5 , the brucite growth kinetics is surface reaction limited and the formation of crystalline clusters are favored [31].

Discontinuous precipitates of gypsum, halite, and silica are located only in the outer layers of the cone-crust (Figure $\left.5 \mathrm{~A}^{\prime}, \mathrm{B}^{\prime}\right)$. Salt deposits are related to the sea spray condensation and dry deposition on the cone-crust surface, whereas silica comes from the dissolution of silicate minerals of mortar aggregates. When these waters flow over the cone-crust, silica precipitates after intense evaporation. Moreover, microbial mediation in silica precipitation in this kind of speleothems cannot be entirely ruled out as it discussed in [30].

\section{Dissolution Events}

Corrosive hiatuses are associated with Mg-depleted lixiviate waters (described in the situation 2 of the Section 5.1). When this water flows over the cone-crust it partially dissolves the pre-existent deposits (Figure 6: A-6). Dissolution affects preferably brucite and salts (brucite is unstable at $\mathrm{pH}$ lower than 9.6) [24], whilst the aragonite layers remain quasi-unaltered. Partial dissolution of pre-existent deposits contributes to develop the puff-pastry aspect of the cone-crust, characterized by big cavities in the brucite masses (Figure 6: A-6). These cavities appear eventually covered by aragonite-brucite precipitates in semi-spherical acicular aggregates (Figure 5I,L; Figure 6: A-7) and are associated to the refilling of the existing gaps with new Mg-enriched lixiviated waters.

\subsubsection{Branching of Coralloids Sequence}

Branching of coralloids forms under subaqueous conditions and its growth is controlled by diffusive feeding of solutes [27]. The aragonite-brucite alternation in the mineral composition of the branching of coralloids (Figure 5D-F) indicates that a relatively homogeneous and constant supply of Mg-enriched lixiviate water arrives to the soda-straw. In contrast to the cone-crust conditions, the soda-straw structure gives a stable environment, keeping it under still conditions and low evaporation rate. The continuity in the coralloid structure, without corrosive scars or brucite partial dissolution, indicates that the inner space of the soda-straw remains isolated from the corrosive events associated to strong rainfalls. Moreover, the absence of salts (gypsum and halite) in the coralloids composition highlights the inaccessibility of sea spray to the inner soda-straw volume.

Branching coralloids grow in a solution with a low supersaturation degree (quasi-saturated solution). When the saturation index for aragonite is exceeded after a certain evaporation degree, it precipitates causing a depletion of solute $\left(\mathrm{Ca}^{2+}\right)$ from the surrounding solution (Figure 6B). As a consequence, aragonite is progressively less saturated in the water near the speleothem and brucite starts to precipitate as a result of the relative $\mathrm{Mg}^{2+}$ enrichment of the solution. Alternatively, $\mathrm{a} \mathrm{Mg}^{2+}-\mathrm{Ca}^{2+}$ concentration gradient is created in the inner of the soda-straw from the farthest to the closest to the coralloid surface (blue dished lines in the Figure 6B), causing diffusion of $\mathrm{Ca}^{2+}$ and $\mathrm{Mg}^{2+}$ toward the growth surface (brown dished arrows in the Figure $6 \mathrm{~B}$ ) and favoring the faster growth on the on the prominences of the coralloid [23,27].

\subsection{Geochemical Model of the Mineral Assemblage}

Speleothems are highly sensitive systems. They are the product of the physic-chemical balance between the geochemical composition of water and that one of the cavity air where they are growing [23]. In this study case, the anthropic structure that host the stalactite establish the hypogean environment necessary for speleothemic growth. These microclimatic conditions are characterized by moderate luminosity and high connection between internal and external environments through several doors and windows. These microclimatic conditions permit the evaporation of lixiviated waters and the deposition of sea spray on speleothems (cone-crust surface). 
As we previously discussed, mortars present an important pore fraction where water-mineral reactions are easily produced. Moreover, they present low permeability values due mainly to the small size of pores. In this geochemical environment, meteoric waters remain a long residence time that leads to Mg-rich waters. We supposed that lixiviated waters are saturated in calcite and unsaturated for dolomite, diopside, and tremolite. As a result, lixiviated waters are unsaturated in aragonite and brucite.

Lixiviated waters become more concentrated by evaporation. Thus, if lixiviated waters are slightly concentrated by 1.2-fold, the resulting waters are saturated in aragonite and supersaturated in calcite, although still undersaturated with respect to brucite. Kinetics factors support the precipitation of aragonite: (1) The nucleation of a metastable phase is kinetically favored over less soluble analogues (aragonite over calcite) because of the lower interfacial energy (and thus lower nucleation energy) between minerals and solution (Ostwald step rule). (2) The presence of magnesium [22] and dissolved silica from the dissolution of siliceous minerals of mortars [32] may inhibit the calcite precipitation and the transformation from aragonite to calcite. The saturation of brucite occurs for the concentration by 1.5 -fold.

The cone-crust over the soda-straw undergoes the sea spray deposition and intensive evaporation. Thus, as in the formation of coralloids, aragonite and brucite firstly precipitate and gypsum and halite, more soluble minerals, grow in the last stage of the precipitation sequence together with silica.

\section{Conclusions}

This study discusses the geochemical weathering processes acting on the constructive geomaterials of the Nueva Tabarca fortress, as well as the main mechanisms involved in the formation of the weathering products.

Studied speleothems are mainly composed of brucite, aragonite, gypsum, halite, and silica. Dolomite, pyroxene, and amphiboles present in mortar aggregates act as $\mathrm{Mg}$-sources, providing Mg-ions to the pore water. Mineral-water interaction is favored by the low permeability of calcitic mortars, which causes long residence times of water flowing through the monument. The highvolume fraction of Mg-bearing minerals in both original and restoration mortars justify the significant magnesium concentration in the lixiviate water. The calculated composition of the lixiviated water using PHREEQC confirms that $\mathrm{Mg}$ concentration is $4.49 \times 10^{-5} \mathrm{~mol} / \mathrm{kg} / \mathrm{H}_{2} \mathrm{O}$, which is critical for the brucite precipitation and the calcite inhibition.

The analysis of the inner structure of the studied stalactite under X-ray computed microtomography allows distinguishing three different parts: (a) the central soda-straw, with smooth cylindrical walls; (b) the cone-crust, characterized by puff-pastry texture; and (c) the inner branching of coralloids. Cone-crust develops discontinuously, alternating constructive events (dominated by mineral precipitation) and corrosive hiatuses (dissolution). Constructive events are associated with precipitation from $\mathrm{Mg}$-enriched lixiviate waters and each event results in the sequent (total or partial) sequence: (1) thin massive aragonite crust in the water-air interface, (2) botryoidal massive aragonite layer, (3) thin fibrous aragonite coating, and (4) massive (or in spherical aggregates) brucite precipitates.

Corrosive hiatuses are associated with Mg-depleted lixiviate waters. These waters are associated with low chemically modified meteoric waters that circulate rapidly through factures and ashlar joins during the torrential rainfalls that characterized the semiarid climate of Nueva Tabarca island. When this water flows over the cone-crust it dissolves partially the pre-existent deposits. Dissolution affects preferably brucite whilst the aragonite layers remain quasi-unaltered. Partial dissolution of pre-existent deposits contributes to develop the puff-pastry aspect of the cone-crust.

Discontinuous precipitates of gypsum, halite, and silica are located in the outer layers of the cone-crust. Salt deposits are related to the sea spray condensation and dry deposition on the cone-crust surface, whereas silica comes from the dissolution of silicate minerals of mortar aggregates.

Branching of coralloids forms under subaqueous conditions and its growth is controlled by diffusive feeding of solutes. The continuity in the coralloid structure indicates that a relatively 
homogeneous and constant supply of Mg-enriched lixiviate water arrives to the soda-straw. Moreover, the absence of corrosive scars and brucite partial dissolution reflects the complete isolation of the inner microenvironment from the corrosive events associated to strong rainfalls.

The PHREEQC model for the evaporation process of Mg-rich lixiviated waters describes the precipitation of the mineral assemblage of the brucite-aragonite speleothems. When lixiviated waters evaporate they are slightly concentrated, and the resulting waters are saturated in aragonite and supersaturated in calcite, although still undersaturated with respect to brucite. The saturation of brucite occurs for the concentration by 1.5-fold. The precipitation of aragonite (instead of calcite) is supported by the fact that the nucleation of a metastable phase (aragonite) is kinetically favored over less soluble analogues (calcite), as well as because of the presence of magnesium and dissolved silica that inhibit the calcite precipitation and the transformation from aragonite to calcite.

Author Contributions: Collecting, processing and analyzing the samples, interpreting the results and writing the original draft, J.M.-M.; analyzing and interpreting the results, finalizing the paper, D.B.; $\mu$ CT-RX analysis and data processing, N.F.; and textural analysis and interpreting results, J.C.C. All authors have read and agreed to the published version of the manuscript.

Funding: This research was funded by project GRE12-03 (University of Alicante).

Acknowledgments: The authors wish to thank José Manuel Pérez Burgos, Felio Lozano, and Antonio Ruso for their disinterested collaboration during the data collection and field works.

Conflicts of Interest: The authors declare no conflict of interest.

\section{References}

1. Beruto, T.D.; Barberis, F.; Botter, R. Clacium carbonate binding mechanisms in the setting of calcium and calcium-magnesium putty-limes. J. Cult. Herit. 2005, 6, 253-260. [CrossRef]

2. Arizzi, A.; Cultrone, G. The diference in behaviour between calcitic and dolomitic lime mortars set under dry conditions: The relationship between textural and physical-mechanical properties. Cem. Concr. Res. 2012, 42, 818-826. [CrossRef]

3. Hartshorn, H. Dolomitic Lime Mortars: Carbonation Complications and Susceptibility to Acidic Sulfates; Columbia University: New York, NY, USA, 2012; p. 193.

4. Lea, F.M. The Chemistry of Cement and Concrete, 3rd ed.; Edward Arnold Ltd.: London, UK, 1970.

5. Danner, T.; Jakobsen, U.H.; Geiker, M.R. Mineralogical sequence of self-healing products in cracked marine concrete. Minerals 2019, 9, 284. [CrossRef]

6. Li, X.; Shui, Z.; Sun, T.; Liu, K.; Wang, X. The hydration mechanism of cement-based materials served in marine environment during early-age magnesium precipitation. Constr. Build. Mater. 2020, 230, 1-8. [CrossRef]

7. Van Tittelboom, K.; De Belie, N. Self-healing in cementitious materials-A review. Mater. Descr. 2013, 6, 2182-2217. [CrossRef]

8. Xu, L.; Ma, X.; Zhan, B.; Zhan, Q.; Zhao, P. Multi-analytical studies of the lime mortars from the Yanxi Hall in the Yangxin Palace of the Palace Museum (Beijing). Archaeometry 2019, 61, 309-326. [CrossRef]

9. He, J.; Bu, X.; Bai, W.; Zhen, W.; Gao, Q.; Wang, Y. Preparation and properties of self-compacting alkali-activated slag repair mortar. Constr. Build. Mater. 2020, 252, 1-13. [CrossRef]

10. Holt, E.E. Early Age Autogenous Shrinkage of Concrete; Technical Research Center of Finland: Espoo, Finland, $2001 ; 446$.

11. Bhagath Singh, G.V.P.; Sonat, C.; Yang, E.H.; Unluer, C. Performance of MgO and MgO-SiO2 systems containing seed under different curing conditions. Cem. Concr. Compos. 2020, 108, 1-12. [CrossRef]

12. Beviá, M.; Giner-Martínez, J. Nunc Minerva postea Palas: La ciudad de Nueva Tabarca. Canelobre 2012, 60, 114-127. (In Spanish)

13. Estévez, A.; Pina, J.A.; Cáliz, F.; Hervás, J.L. Isla Plana o Nueva Tabarca: Significación geológica y evolución tectónica reciente en el contexto del sector oriental de las Cordilleras Béticas. In La Reserva Marina de La Isla Plana o Nueva Tabarca; Universidad de Alicante: Alicante, Spain, 1985; pp. 25-35. (In Spanish)

14. Corbí, H.; Martínez-Martínez, J.; Martín-Rojas, I. Linking geological and architectural heritage in a singular Geosite: Nueva Tabarca island (SE Spain). Geoheritage 2019, 11, 703-716. 
15. Kampschuur, U.; Simon, O.J. Sur la géologie de l'ile de Tabarca (prov. d'Alicante, Espagne). Som C. R. SGF 1969, 2, 37-38.

16. Calvet, F.; Zamarreño, I.; Vallés, D. Late Miocene reefs of the Alicante-Elche basin. In Models for Carbonate Stratigraphy from Miocene Reef Complexes of Mediterranenan Regions; SEPM: Boken Arrow, OK, USA, 1996.

17. Martínez-Martínez, J.; Corbí, H.; Martin-Rojas, I.; Baeza-Carratalá, J.F.; Giannetti, A. Stratigraphy, petrophysical characterization and 3D geological modelling of the historical quarry of Nueva Tabarca island (western Mediterranean): Implications on the heritage conservation. Eng. Geol. 2017, 231, 88-99.

18. Martínez-Martínez, J.; Benavente, D.; Jiménez Guitérrez, S.; García-del-Cura, M.A.; Ordóñez, S. Stone weathering under Mediterranean semiarid climate in the fortress of Nueva Tabarca island (Spain). Build. Environ. 2017, 121, 262-276. [CrossRef]

19. Fort, R.; Bernabéu, A.; García-del-Cura, A.; López de Azcona, M.C.; Ordóñez, S.; Mingarro, F. Novelda Stone: Widely used within the spanish architectural heritage. Mater. Constr. 2002, 52, 19-32. [CrossRef]

20. Parkhurst, D.L.; Appelo, C.A.J. Description of input and examples for PHREEQC version 3-a computer program for speciation, batch-reaction, one-dimensional transport, and inverse geochemical calculations. In Technieques and Methods, US Geological Survey Techniques and Methods, book 6; USGS: Renton, VA, USA, 2013; p. 497.

21. Appelo, C.A.J.; Postma, D. Geochemistry, Groundwater and Pollution. Balkema: Rotterdam, The Netherlands, 1993; p. 536.

22. Langmuir, D. Aqueous Environmental Geochemistry; Prentince-Hall Inc.: Upper Saddle River, NJ, USA, 1997.

23. Self, C.A.; Hill, C.A. How speleothems grow: An introduction to the ontogeny of cave minerals. J. Cave Karst Stud. 2003, 62, 130-151.

24. Giampouras, M.; Garrido, C.J.; Bach, W.; Los, C.; Fussmann, D.; Monien, P.; García-Ruiz, J.M. On the Controls of Mineral Assemblages and Textures in Alkaline Springs, Smail Ophiolite, Oman. Chem. Geol. 2020, 533, 119435. [CrossRef]

25. Liu, A.; Yuan, D.; Dreybrodt, W. Comparative study of dissolution rate-determining mechanisms of limestone and dolomite. Environ. Geol. 2005, 49, 274-279. [CrossRef]

26. Benavente, D.; Pla, C.; Cueto, N.; Galvañ, S.; Martínez-Martínez, J.; García-del-Cura, M.A.; Ordóñez, S. Predicting water permeability in sedimentary rocks from capillary imbibition and pore structure. Eng. Geol. 2015, 195, 301-311. [CrossRef]

27. Caddeo, G.A.; Railsback, L.B.; De Waele, J.; Frau, F. Stable isotope data as constraints on models for the origin of coralloid and massive speleothems: The interplay of substrate, water supply, degassing and evaporation. Sediment. Geol. 2015, 318, 130-141. [CrossRef]

28. Liu, H.; Huang, H.; Wu, X.; Peng, H.; Li, Z.; Hu, J.; Yu, Q. Effects of external multi-ions and wet-dry cycles in a marine environment on autogenous self-healing of cracks in cement paste. Cem. Concr. Res. 2019, 120, 198-206. [CrossRef]

29. Dang, D.N.; Gascoin, S.; Zanibellato, A.; Da Silva, C.G.; Lemoine, M.; Riffault, B.; Sabot, R.; Jeannin, M.; Chateigner, D.; Gil, O. Role of brucite dissolution in calcium carbonate precipitation from artificial and natural seawaters. Cryst. Growth Des. 2017, 17, 1502-1513. [CrossRef]

30. Vanghi, V.; Borsato, A.; Frisia, S.; Howard, D.L.; Gloy, G.; Hellstrom, J.; Bajo, P. High-resolution synchrotron $\mathrm{X}$-ray fluorescence investigation of calcite coralloid speleothems: Elemental incorporation and their potential as environmental archives. Sedimentology 2019, 66, 2661-2685. [CrossRef]

31. Maltseva, A.; Shkirskiy, V.; Lefèvre, G.; Volovith, P. Effect of $\mathrm{pH}$ on $\mathrm{Mg}(\mathrm{OH}) 2$ film evolution on corroding $\mathrm{Mg}$ by in situ kinetic Raman mapping (KRM). Corros. Sci. 2019, 153, 272-282. [CrossRef]

32. Kellermeier, M.; Glaab, F.; Klein, R.; Melero-García, E.; Kunz, W.; García-Ruiz, J.M. The effect of silica on polymorphic precipitation of calcium carbonate: An on-line energy-dispersive X-ray diffraction (EDXRD) study. Nanoscale 2013, 5, 7054-7065. [CrossRef] [PubMed]

(C) 2020 by the authors. Licensee MDPI, Basel, Switzerland. This article is an open access article distributed under the terms and conditions of the Creative Commons Attribution (CC BY) license (http://creativecommons.org/licenses/by/4.0/). 